\title{
På vandring
}

\section{Den norske turistforening -} Norges største helseforebyggende organisasjon - gjør vi vårt beste for at flest mulig skal få lyst til å bevege seg mer i skog og mark.

For å få det til prøver vi å tilrettelegge og aktivt markedsføre våre tilbud. Ikke bare våre 270000 medlemmer benytter seg av tilbudene. Stadig flere opplever gleden og nytten av å benytte godt tilrettelagte turstier i sine nærmiljøer. Det er den daglige vandringen som teller aller mest - både i forhold til fysisk og psykisk helse. På mine reiser rundt til medlemsforeningene våre i Norge er det utrolig inspirerende å møte den eldre garden som bygger hytter, vedlikeholder stier og rett og slett har et strålende sosialt fellesskap - i sterk kontrast til dem som i relativt tidlig alder ikke har mulighet til dette på grunn av livsstilssykdommer.

Selv har jeg gått mye i fjellet og det har gjort godt for min helse. Jeg er ikke så ofte innom legen i dag, men hadde et år på vandring mellom ulike leger på slutten av 80 -årene. Jeg hadde sterke udefinerte smerter som ble håndtert med acetylsalisylsyre ca. hver tredje time i et års tid. Det mest frustrerende var å gjenta sykehistorien hver gang jeg kom til en ny lege og en ny unders $\varnothing$ kelse. Hvor var kartet mitt for finne frem i dette ukjente terrenget? Det var ingen informasjon tilgjengelig over hva som var gjort hos andre. Med over middels analytiske og strukturerte evner endte det opp med at jeg laget en logg over tidligere undersøkelser som jeg hadde med meg rundt. Etter et års tid var jeg til undersøkelse på Martine Hansens hospital, og helt tilfeldig kom det en lege innom som kikket på et røntgenbilde og konstaterte at problemet var osteoid osteom - en godartet svulst i lårbeinet. Ingen av de andre var i stand til å se det på bildet, men han hadde heldigvis tatt doktorgrad på temaet. Følelsen av å være smertefri ganske direkte etter operasjonen var spesiell. Selv om dette var en relativt enkel operasjon fikk det i alle fall meg til å reflektere over at når man først har funnet årsaken, er det ganske utrolig hva man i dag er i stand til å korrigere.

Veien frem til å finne årsaker til plagene er fortsatt i mange tilfeller svært lang spesielt for mange av de diffuse plagene. Det ser jeg også er tilfelle i dag med personer jeg kjenner, som har vært i tilsvarende situasjon, og journalene flyter fortsatt ikke så lett som de burde. Spesialistene er kanskje blitt enda mer spesialiserte, uten at dialogen på tvers er god nok. Slik ser det i alle fall ut utenfra. Mitt første møte med et sykehus sett fra innsiden skjedde på Haukeland universitetssykehus. Min mor fikk lungekreft og døde der etter noen måneders opphold i 1979, bare 44 år gammel. Jeg var student da og ble dermed sittende mye å lese hos henne på sykehuset. Hun hadde aldri røyket og hadde en sunn livsstil, så det var ikke lett å akseptere. Jeg ble imponert over det faglige miljøet og omsorgen som ble vist fra sykepleiernes side. Siden har jeg hatt en enorm respekt for dem som har evnen til å arbeide i et svært stressende miljø med sterke følelser involvert.

Lite har frustrert meg så mye som mangelen på gode integrerte pasientadministrative systemer i helsesektoren. Norge som var verdensledende med gode systemer innen banksektoren allerede i de tidlige 80-årene, var ikke i nærheten av å kunne møte pasienter på en tilsvarende måte. Det erfarte jeg da jeg var med på å utvikle store IT-systemer i Norge og ledet et av de største konsulentselskapene som i den senere tid har vært involvert i arbeid for flere av helseforetakene. Når man jobber med slike omfattende systemer, har man store muligheter til å påvirke og forbedre pasientens hverdag. Denne hverdagen ønsker vi i Den norske turistforening også å være med på.

Et av våre satsningsområder er å prøve å få så mange som mulig til å vandre i vår flotte natur. Turistforeningen har et inkluderende turtilbud for alle, uansett alder og form. Det å komme seg ut i naturen er med på å forebygge livsstilssykdommer og gjør godt for kropp og sinn.

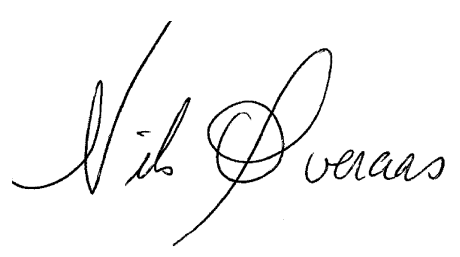

